\title{
IMPLEMENTASI TUGAS HAKIM PENGAWAS DAN \\ PENGAMAT TERHADAP NARAPIDANA PADA \\ LEMBAGA PEMASYARAKATAN \\ KELAS II A JAMBI
}

\author{
Oleh : \\ Bahrun * \\ Ferdricka Nggeboe * \\ Nuraini *
}

\begin{abstract}
ABSTRAK
Implementasi tugas Hakim Pengawas dan Pengamat dalam melakukan pengawasan dan pengamatan terhadap narapidana di Lembaga Pemasyarakatan Kelas II A Jambimerupakan seperangkat kegiatan yang secara nyata telah dilakukan oleh hakim yang ditunjuk Ketua Pengadilan sebagai Hakim Pengawas dan Pengamat untuk melakukan pengamatan terhadap narapidana selama mereka menjalani masa pidanaya terutama mengenai perilaku mereka masing-masing maupun perlakuan para petugas Lembaga Pemasyarakatan terhadap diri narapidana itu sendiri. Dengan demikian hakim selain akan dapat mengetahui sampai dimana putusan pengadilan tampak hasil baik buruknya pada diri narapidana yang bersangkutan, juga penting bagi penelitian yang bermanfat bagi pemidanaan. Ditemukan hambatan- hambatan selaku Hakim pengawas dan pengamat dalam menjalankan tugas dan wewenangnya, maka diperlukan pengaturan sebaiknya dimasa depan tentang peranan Hakim Pengawas dan Pengamat yang sebaiknya diterapkan adalah norma hukum acara pidana yang mengatur secara jelas dan tegas tentang peranan Hakim Pengawas dan Pengamat terhadap perubahan perilaku narapidana, sedemikian sehingga setiap terjadinya penjatuhan pidana, dapat dipastikan bahwa terpidana tidak akan melakukan resedivisme, melalui mekanisme pengawasan dan pengamatan oleh Hakim Pengawas dan Pengamat, yang sebagian fungsinya dilimpahkan kepada Ketua RT/Desa/Kelurahan domisili narapidana dan Balai Pemasyarakatan.
\end{abstract}

Kata Kunci: Implementasi, Hakim Pengawas dan Pengamat, Lembaga Pemasyarakatan Kelas II A Jambi

\section{A. Latar Belakang Masalah}

Hakim dalam menjatuhkan pidana memperhitungkan sifat perbuatan pidana dan keadaan si pembuat serta perkembangan konsepsi individualisasi pidana sebagai pengaruh dari kriminologi yang mendorong adanya perhatian terhadap pribadi terdakwa sebagai pertimbangan hakim dalam menjatuhkan putusan pidana. Konsep inilah yang sering dinamakan sistem dua jalur (Twintrack system)dimana individualisasi pidana juga dipertimbangkan (Punishmentshould fit the criminal). ${ }^{1}$

\footnotetext{
* PNS di Pengadilan Tinggi Jambi, Alumni Program Magister Ilmu Hukum Unbari.

* Pengajar Program Magister Ilmu Hukum Unbari.

* Pengajar Program Magister Ilmu Hukum Unbari.

${ }^{1}$ Sudarto, Kapita Selekta Hukum Pidana, Alumni, Bandung, 1986, hal. 13
} 
Menurut Undang-Undang Nomor 48 Tahun 2009 tentang Kekuasaan Kehakiman, memandang perlu adanya pengawasan dan pelaksanaan putusan pengadilan sebagaimana diatur dalam Pasal 55 ayat (1) dan (2) Undang-Undang Nomor 48 Tahun 2009 tentang Kekuasaan Kehakiman yang menentukan sebagai berikut :

1. Pelaksanaan putusan pengadilan dalam perkara pidana dilakukan oleh Jaksa

2. Pengawasan pelaksanaan putusan pengadilan tersebut ayat (1) oleh Ketua Pengadilan yang bersangkutan berdasarkan undang-undang.

Hal ini menegaskan bahwa untuk mendapatkanjaminan bahwa putusan pengadilantersebut dilaksanakan sebagaimana mestinya, Ketua Pengadilan yang bersangkutan mengawasi pelaksanaan tersebut.Ketentuan tentang pengawasan dan pengamatan pelaksanaan putusan pengadilandiatur pula dalam Undang-Undang Nomor 8 Tahun 1981 tentang Kitab Undang-Undang Hukum Acara Pidana (KUHAP) tangggal 31 Desember 1981 Lembaran Negara Tahun 1981 Nomor 76 dan Tambahan Lembaran Negara Nomor 3209) yang menggantikan Het Herzien Indonesisch Reglement yang disingkat dengan HIR(S.1941-44 jo. S. 1948-224) yaitu Bab XX tentang Pengawasan dan Pengamatan Pelaksanaan Putusan Pengadilan, Pasal 277 sampai dengan Pasal 283.Bab XX KUHAP mengatur kewenangan Ketua Pengadilan Negeri sebagaimanadimaksud oleh Pasal 55 ayat (2) Undang-Undang Nomor 48 Tahun 2009 tentang Kekuasaan Kehakiman didelegasikan kepada Hakim yang disebut dengan Hakim Pengawas dan Pengamat sebagaimana diatur dalam Pasal 277 KUHAP sampai dengan Pasal 283 KUHAP. Selain itu di dalam KUHAP dan Undang-Undang Nomor 48 Tahun 2009 tentang Kekuasaan Kehakiman, pengaturan tentang Hakim Pengawas dan Pengamat juga diatur dalam Surat Edaran Mahkamah Agung Nomor 3 Tahun 1984 tentang Pelaksanaan Tugas Hakim Pengawas dan Pengamat serta Surat Edaran Mahkamah Agung Nomor 7 Tanggal 11 Februari Tahun 1985 tentang Petunjuk Pelaksanaan Tugas Hakim Pengawas dan Pengamat. Tugasnya adalah mengontrol pelaksanaan putusan pengadilan (pidana penjara dan kurungan) semenjak putusan memperoleh kekuatan hukum tetap sampai selesai pelaksanaanya, dengan wewenangnya mengoreksi secara langsung aparat yang melalaikan atau menyimpang dari putusan yang telah dijatuhkan.

Dalam kaitannya dengan tugas pengawasan dan pengamatan,kemanfaatan yang paling utama dalam peraturan Bab XX KUHAP bukan terletakpada tugas pengawasannya, akan tetapi terletak pada tugas pengamatannya sebagai bahan penelitian hasil guna penjatuhan pidana. 
Alasan yang diberikannya adalah, Hakim dalam tugas khusus ini turut melakukan pendekatan secara langsung, agar dapat mengetahui sampai di mana hasil baik atau buruknya pada diri narapidana atas putusan hakim yang bersangkutan. Usaha pendekatan dari Hakim ini akan menambah kemampuan di bidang hukum penitensierdan pengenalan atas penerapan penologi sehingga Hakim tidak lagi sekedar tukang putus hukuman tanpa ikut memikirkan manfaat putusannya.

Untuk menunjang keberhasilan pelaksanaan putusan pengadilan, maka di dalam Kitab Undang-Undang Hukum Acara Pidana (KUHAP), telah diatur tentang keharusan bagi setiap pengadilan untuk menunjuk Hakim yang diberikan tugas khusus untuk membantu Ketua Pengadilan Negeri dalam melakukan pengawasan dan pengamanan terhadap putusan pengadilan yang menjatuhkan pidana perampasan kemerdekaan. ${ }^{2}$

Hal ini sesuai dengan ketentuan dari Pasal 277 ayat (1) KUHAP yang menentukan bahwa :

Pada setiap pengadilan harus ada Hakim yang diberi tugas khusus untuk membantu ketua dalam melakukan pengawasan dan pengamatan terhadap putusan pengadilanyang menjatuhkanpidana perampasan kemerdekaan.

Selain itu, menurut ketentuan Pasal 277 ayat (2) KUHAP juga dijelaskan mengenai jangka waktu atau masa kerja Hakim Pengawas dan Pengamat dalam melaksanakan pengawasan dan pengamatan tersebut. Jangka waktu dalam pelaksanaan pengawasan dan pengamatan oleh Hakim Pengawas dan Pengamat tersebut berlaku paling lama dalam waktu 2 (dua) tahun. Adapun isi dari ketentuan Pasal 277 ayat (2) KUHAP menentukan bahwa :

Hakim sebagaimana dimaksud dalam ayat (1) yang disebutHakim Pengawas dan Pengamat, ditunjuk oleh Ketua Pengadilan untuk paling lama 2 (dua) tahun.

Hakim Pengawas dan Pengamat pada dasarnya mempunyai 2 (dua) tugas pokokdalam pelaksanaan putusan pengadilan yaitu pengawasan dan pengamatan. Ketentuan mengenai pengawasan oleh Hakim Pengawas dan Pengamat dinyatakan dalam Pasal 280 ayat (1) KUHAP yang menentukan bahwa:

"Hakim Pengawas dan Pengamat mengadakan pengawasan guna memperoleh kepastian bahwa putusan pengadilan dilaksanakan sebagaimana mestinya."

Artinya, bahwa hakim yang mempunyaitugas khusus tersebut, lakukan pengawasan untuk menjamin bahwa putusan mengenai penjatuhan pidana perampasan kemerdekaan itu

\footnotetext{
${ }^{2}$ Oemar Seno Adji, Hukum Hakim Pidana, Erlangga, Jakarta,1989, hal. 8
} 
benar-benar telah dilaksanakan sebagaimana mestinya sesuai asas perikemanusiaan dan perikeadilan dan hal ini untuk mencegah timbulnya anggapan dari masyarakat bahwa putusan pengadilan itu hanya dijadikan sebagai simbol saja. ${ }^{3}$

Adapun ketentuan mengenai pengamatan, olehHakim Pengawas dan Pengamat dinyatakan dalam Pasal 280 ayat (2) KUHAP yang menentukan bahwa:

Hakim Pengawas dan Pengamat mengadakan pengamatan untuk bahan penelitian demi ketetapan yang bermanfaat bagi pemidanaan yang diperoleh dari perilaku narapidana atau pembinaan Lembaga Pemasyarakatan serta pengaruh timbal balik terhadap narapidana selama menjalani pidananya.

Artinya bahwa, di dalam pengamatan Hakim Pengawasdan Pengamat melakukan pengamatan terhadap narapidana selama mereka menjalani masa pidananya terutama mengenai perilaku mereka masing-masing maupun perlakuan para petugas dari Lembaga Pemasyarakatan terhadap diri narapidana itu sendiri.

Dengan demikian, Hakim selain akan dapat mengetahui sampai dimana putusan pengadilan tampak hasil baik buruknya pada diri narapidana yang bersangkutan, juga penting bagi penelitian yang bermanfaat bagi pemidanaan.

Dengan adanya penjelasan tersebut diatas dapat diartikan bahwa peranan Hakim Pengawasdan Pengamat di dalam pengawasan dan pengamatan terhadap pelaksanaan putusan pengadilan berkaitan erat dengan Lembaga Pemasyarakatan,sehingga kerjasama di antara Hakim Pengawas dan Pengamat dengan Lembaga Pemasyarakatan mengenai hubungan kerja tersebut diatur di dalam KUHAP yaitu Pasal 277 sampai dengan Pasal 283 KUHAP.

Semua penjelasan tersebut di atas merupakan ketentuan mengenai tugas dari Hakim Pengawas dan Pengamat dalam mengadakan pengawasan dan pengamatan terhadap pelaksanaan putusan pengadilan yang ditujukan kepada narapidana yang sedang menjalani masa pidananya, khususnya didalam Lembaga Pemasyarakatan.

Namun, menurut ketentuan KUHAP, bahwa pengawasan dan pengamatan hakim tidak hanya terbatas di dalam Lembaga Pemasyarakatan saja, tetapi juga di luar Lembaga Pemasyarakatan.Hal ini tercantum di dalam Pasal 280 ayat (3) KUHAP yang menentukanbahwa Pengamatan sebagaimana yang dimaksud dalam ayat (2) tetap dilaksanakan setelah terpidana selesai menjalani pidananya.

3 Suryono Sutarto, Sari Hukum Acara Pidana, Yayasan Cendikia Purna Dharma, Semarang, 1990, hal. 10. 
Ini berartibahwa, peranan Hakim Pengawas dan Pengamat tidak hanya terbatas mengawasi dan mengamati narapidana selama menjalani masa pidananya di Lembaga Pemasyarakatan saja, tetapi di sini juga mengawasi dan mengamati narapidana setelah dia keluar dari Lembaga Pemasyarakatan atau telah selesai masa pidananya dan kembali ke dalam masyarakat. ${ }^{4}$

Lembaga Pemasyarakatan sebagai tempat bagi narapidana wajib membina narapidananya, agar sesudah menyelesaikan masa hukumannya dapat diterimadalam masyarakat, sehingga dalam hal ini Hakim Pengawas dan Pengamat dengan kewenangannya memeriksa tentang pelaksanaan putusan pengadilan sudah dijalankan dengan benar atau tidak dan juga dengan pembinaan terhadap narapidananya. Berdasarkan observasiawal penulis, di Lembaga Pemasyarakatan Klas IIA Jambi, peran Hakim Pengawas dan Pengamat dalam ikut serta membina narapidana belum berjalan dengan lancar, bahkan boleh dikata kurang tampak aktivitasnya.

Dengan ikut campurnya Hakim dalam pengawasan dan pengamatan tersebut, maka selain hakim akan mengetahui sampai dimana putusan pengadilan itu tampak hasil baik buruknya padadiri narapidana masing-masing yang bersangkutan, juga penting bagi bahan penelitian demi ketepatan dalam pemidanaan.

Adanya model pembinaan bagi narapidana di dalam Lembaga Pemasyarakatan terlepas dari sebuah dinamika, yang bertujuan untuk lebih banyak memberikan bekal bagi narapidana dalam menyongsong kehidupan setelah selesai menjalani masa hukuman (bebas).Seperti halnya yang terjadi jauh sebelumnya, peristilahan penjara pun telah mengalami perubahan menjadi pemasyarakatan.Tentang lahirnya istilah Lembaga Pemasyarakatan dipilih sesuai dengan visi dan misi lembaga itu untuk menyiapkan narapidana kembali ke masyarakat.Pemasyarakatan dinyatakan sebagai suatu sistem pembinaan terhadap para pelanggar hukum dan sebagai suatu pengejawantakan keadilan yang bertujuan untuk mencapai reintegrasi sosial atau pulihnya kesatuan hubungan antara Warga Binaan Pemasyarakatan dengan masyarakat.

Hukuman terlalu berat atau terlalu ringan dari yang sewajarnya atas suatu kejahatan adalah merupakan putusan yang tidak adil.Ini menggambarkan tidak berhasilnya pengadilan memberikan pidana yang dapat memperbaiki pelaku kejahatan, sehingga menggoyahkan kepercayaan masyarakat kepada hukum.Selanjutnya hal ini dapat

\footnotetext{
${ }^{4}$ Yahya Harahap, Pembahasan permasalahan dan Penerapan KUHAP, Garuda Metropolitan Press, Jakarta, 1998, hal. 32
} 
mendorong parapelaku kejahatan lebih berani melakukan perbuatannya. Sebagian dari mereka mungkin merasa dirinya kebal hukum, demikian pula ketidak terpaduan antara pengadilan dengan Lembaga Pemasyarakatan dapat menambah ketidak percayaan pada hukum sebab bekas narapidana gagal berintegrasi kembali dengan masyarakat atau lebih parah lagi mempunyai "rasa dendam" pada masyarakat, karena diperlakukan sewenangwenang dalam Lembaga Pemasyarakatan.

Keadaan ini, dapat memberi peluang timbulnya residivis.Proses Sistem Peradilan Pidana (SPP) dengan masing-masing sub sistemnya diharapkan menjadi tumpuan harapan penegakan hukum dalam Negara Republik Indonesia yang berdasarkan hukum, dalam melaksanakan pembangunannya untuk mencapai masyarakat adil dan makmur. Dan apa yang menjadi tujuan SPP sulit dicapai. Melindungi, mengamankan dan menenteramkan masyarakat sebagai bagian lain dari misi Sistem Peradilan Pidana belum banyak pula dirasakan masyarakat.Demikian juga pelaku-pelaku kriminal yang telah melalui dan menjalani peradilan pidana.

Hal tersebut menunjukkan bahwa belum berjalannya proses pembinaan narapidana dengan baik padahal sub sistem Lembaga Pemasyarakatan pada hakekatnya mempunyai fungsi dan kedudukan yang sangat strategis untuk membina narapidana kembali baik ke masyarakat itu sekaligus memberikan gambaran tentang keberhasilan kinerjanya Sistem Peradilan Pidana dalam penegakan hukum secara keseluruhan.

Romli Atmasasmita mengemukakan bahwa "kritik pedas sering dilontarkan pada Lembaga Pemasyarakatan sebagai aparat penegak hukum dalam hal terjadinya pelarian narapidana atau tahanan, narapidana mati di dalam Lembaga Pemasyarakatan". 5

Padahal pelanggar hukum itu adalah berasal dari masyarakat dan akankembali ke masyarakat baik sebagai warga yang taat kepada hukum maupun mereka yang kemudian mengulangi kembali kejahatan baik sebagai residivis maupun non residivis. Tujuan ini hanya dapat tercapai dengan baik apabila kedua lembaga yaitu sub sistem pengadilan dihubungkan dekat dengan sub sistem Lembaga Pemasyaraktan oleh Hakim pengawas dan pengamat yang di tunjuk oleh Ketua Pengadilan Negeri untuk mengawasi pelaksanaan hukuman dan hak-hak narapidana sebagaimana mestinya.

Efektifitas keterpaduan kedua sub sistem tersebut diatas dapat lebih ditingkatkan dengan berjalannya peranan Hakim pengawas dan pengamat (Hakim Pengawas dan 1996,hal. 7

${ }^{5}$ Romli Atmasasmita, Sistem Peradilan, Perspektif Eksistensi, PT. PradnyaParamita, Jakarta, 
Pengamat) yang diatur dalam Undang-Undang sebagai penghubung yang mendekatkan kedua lembaga tersebut, Khususnya dalam hal pidana perampasan kemerdekaan (pidana penjara) ketepatan putusan pengadilan tersebut masih perlu diuji.

Ketentuan mengenai Hakim Pengawas dan Pengamat dalam KUHAP diatur cukup ideal, tetapi dalam praktik, ketentuan KUHAP tersebut tidak berjalan. Adapun beberapa hal yang diidentifikasikan sebagai faktor penyebab adalah

1. Hakim yang ada di tiap-tiap pengadilan sering kali sudah disibukkan dengan tugas-tugas rutin peradilan, sehingga tugas sebagai Hakim Pengawas dan Pengamat terabaikan,

2. Kurangnya personil Hakim yang ada pada pengadilan, sehingga tugas sebagai Hakim Pengawas dan Pengamat tidak dapat dijalankan,

3. Kurangnya koordinasi dan kooperasi antar berbagai aparat penegak hukum,. Dalam hal ini tiap-tiap institusi penegak hukum sering kali masih mementingkan terlaksananya tugas masing-masing tanpa memikirkan kebutuhan institusi penegak hukum yang lain berkaitan dengan proses peradilan pidana. ${ }^{6}$

Bagi Hakim Pengawas dan Pengamat, dalam melaksanakan tugasnya selain KUHAP dan Pedoman PelaksanaanKUHAP sebagai dasar hukumnya, dilengkapi pula dengan :

1. Surat Edaran Mahkamah Agung Republik Indonesia (SEMA)Nomor 3Tahun 1984 Tentang Pelaksanaan Tugas Hakim Pengawas dan Pengamat.

2. Surat Edaran Mahkamah Agung Republik Indonesia (SEMA) Nomor 7 Tahun 1985 Tentang Petunjuk Pelaksanaan Tugas Hakim Pengawas Dan Pengamat.

Hakim Pengawas dan Pengamat mempunyai tugas khusus selama 2 (dua) tahun untuk membantu Ketua Pengadilan Negeri dantugas itu dilakukan dengan tujuan untuk memperoleh kepastian bahwa putusan pengadilan telah dilaksanakan sebagaimana mestinya dan juga digunakan untuk bahan penelitian demi ketetapan yang bermanfaat bagi pengaruh pemidanaan dan timbal balik dengan melihat tingkah laku narapidana.

${ }^{6} \mathrm{Al}$ Wisnubroto dan G Widiartana, Pembaharuan Hukum Acara Pidana, Citra Aditya, Bandung, 2005, hal. 109 
Dalam menjalankan dan pengamatan putusan pengadilan, Hakim Pengawas dan Pengamat lebih bersifatadministratif dan pasif, yaitu menunggu laporan dari Jaksa berkaitan dengan pelaksanaan putusan pengadilan.

Tugas pengawasan dan pengamatan dilaksanakan oleh Hakim Pengawas dan Pengamat setelah Ketua Majelis menjatuhkan putusan pengadilan yang telah memperoleh kekuatan hukum tetap. Objek dari pengawasan dan pengamatan yang dilakukan oleh HakimPengawas dan Pengamat adalah pelaksana putusan dan narapidana.

Ketentuan ini disebutkan dalam Pasal 54 ayat (1) Undang-Undang Nomor48 Tahun 2009 tentang Kekuasaan Kehakiman.Dalam SEMA Nomor 7 Tahun 1985 Tentang PetunjukPelaksanaan Tugas Hakim Pengawas Dan Pengamat, menyebutkan bahwa Hakim Pengawas dan Pengamat (Pengawas dan Pengamat) harus datang ke Lembaga Permasyarakatan untuk mengadakan checking on the spot paling sedikit 3 (tiga) bulan sekali untuk memeriksa kebenaran berita acara pelaksanaan putusan pengadilan. Hakim Pengawas dan Pengamat ini sangat dibutuhkan dan penentuannya dilakukan oleh Ketua Pengadilan Negeri, minimal 1 (satu) orang Hakim Pengawas dan Pengamat di sebuah Pengadilan Negeri, selebihnya tergantung pada volume dari putusan pengadilan yang sudah mempunyai kekuatan hukum tetap. Hakim Pengawas dan Pengamat berada di Pengadilan Negeri dengan masa jabatan maksimal selama 2 (dua) tahun, yang diangkat dan diganti oleh Ketua Pengadilan Negeri yang mempunyai wewenang untuk mengangkat dan menggantikan dengan Hakim lain.

Meskipun pengaturan tugas Hakim Pengawas dan Pengamat sudah diatur dalam peraturan perundang-undangan yang telah ada, akan tetapi pelaksanaannya masih mengalami beberapa hambatan karena ada beberapa faktor yang mempengaruhinya. Menurut Soerjono Soekanto,masalah pokok dari penegakan hukum sebenarnya terletak pada faktor yang mempengaruhinya. Faktor-faktor tersebut antara lain :

1. Faktor hukumnya sendiri

Dalam hal ini di batasi pada undang-undang saja.Undang-undang di sini adalah undang-undang dalam arti materiil, yaitu peraturan yang tertulis.

2. Faktor penegakkan hukumnya

Ruang lingkup dari istilah penegakkanhukum adalah luas sekali, oleh karena itu mencakup mereka yang secara langsung atau tidak langsung 
berkecimpung di bidang penegakkan hukum. Mereka adalah yang bertugas di Kepolisian, Kejaksaan, Kepengawasan, Kehakiman dan Lembaga Pemasyarakatan.

3. Faktor sarana dan fasilitas

Penegakkan hukum tidak mungkin berlangsung dengan lancar tanpa adanya sarana dan fasilitas tertentu. Sarana dan fasilitas tersebut antara lain mencakup Sumber Daya Manusia (SDM) yang berpendidikan dan terampil, organisasi yang baik, peralatan yang memadai, keuangan yang cukup, dan sebagainya. Kalau hal ini tidakterpenuhi, mustahil penegakkan hukum akan mencapai tujuan.

4. Faktor masyarakat

Penegakkan hukum berasal dari masyarakat dan tujuan untukmencapai kedamaian dalam masyarakat. Oleh karena itu, masyarakatdapat mempengaruhi penegakkan hukum.

5. Faktor kebudayaan

Kebudayaan hukum pada dasarnya mencakup nilai-nilai yang mendasari hukum yang berlaku, nila-nilai yang mana merupakankonsepsikonsepsi abstrak mengenai apa yang dianggapbaik (sehingga diikuti) dan apa yang dianggap buruk (sehingga di hindari). ${ }^{7}$

Kehadiran Hakim Pengawas dan Pengamat dalam ikut mengawasi pelaksanaan putusan pengadilan serta pelaksanaan pidana penjara, diharapkan dapat menjadi suatu bentuk kepedulian dalam rangka ikut memikirkan nasib para narapidana. Di samping sebagai pengontrol dilaksanakannya putusan pengadilan, keberadaan Hakim Pengawas dan Pengamat diharapkan pulaikut menunjang keberhasilan pembinaan narapidana itu sendiri.

\section{B. Perumusan Masalah}

Adapun pertanyaan-pertanyaan penelitian yang memfokuskanpermasalahan di atas adalah:

1. Bagaimana implementasi tugas Hakim pengawas dan pengamat terhadap Narapidana di Lembaga Pemasyarakatan Klas IIA Jambi?;

7 Soerjono Soekanto, Faktor-Faktor Yang Mempengaruhi Penegakkan Hukum, Rajawali, Jakarta, 1983, hal. 4 
2. Apa saja yang menjadi hambatan dalam pelaksanaan tugas Hakim pengawas dan pengamat tersebut dan bagaimana solusinya?;

3. Bagaimanakah pengaturan sebaiknya dimasa yang akan datang?.

\section{Metode Penelitian}

1. Spesifikasi Penelitian

Penelitian ini bersifat deskriptif, dimana penulis lebih mengutamakan kepada tujuan untuk menggambarkan fenomena yang berhubungan dengan objek yang sedang diteliti, sehingga yang dikaji adalah implementasi tugas Hakim pengawas dan pengamat terhadap Narapidana di Lembaga Pemasyarakatan Klas IIA Jambi.

\section{Metode Pendekatan}

Penelitian ini dilakukan dengan menggunakan pendekatan "Yuridis Sosiologis", yaitu melalui pengkajian peraturan perundang-undangan tentang implementasi tugas Hakim pengawas dan pengamat terhadap Narapidana di Lembaga Pemasyarakatan Klas IIA Jambi dengan peraturan perundang-undangan terkait.

Data-data primer yang diperoleh pada penelitian lapangan dikumpulkan, kemudian diolah dan diklasifikasikan kedalam bagian-bagian tertentu, untuk seterusnya dianalisis.Analisis data dilakukan secara kualitatif, yaitu dengan menelaah implementasi tugas Hakim pengawas dan pengamat terhadap Narapidana di Lembaga Pemasyarakatan Klas IIA Jambi kemudian hasil dari jawaban responden yang diteliti dituangkan

\section{Implementasi Tugas Hakim Pengawas Dan Pengamat Terhadap Narapidana Pada Lembaga Pemasyarakatan Klas Iia Jambi}

1. Implementasi Tugas Hakim Pengawas Dan Pengamat Terhadap Narapidana.

Komponen sistem peradilan pidana, baik dalam pengetahuan mengenai kebijakan pidana (criminal policy) maupun dalam lingkup praktik penegakan hukum, terdiri atas unsur Kepolisian, Kejaksaan, Pengadilan, dan Lembaga Pemasyarakatan.

Sejalan dengan pokok permasalahandalampenelitianini, maka analisis atau pembahasan akan lebih ditekankan pada implementasi bekerjanya lembaga penegak hukum, dalam sistem peradilan pidana Indonesia yang terdiridari subsistem Kepolisian, Kejaksaan, Pengadilan,dan Lembaga Pemasyarakatan merupakan alat penegak hukum dalam suatu jaringan yang tidak dapat dipisahkan satu dengan yang lainnya. Salah satu subsistem yang mempunyai kedudukan sentral adalah pengadilan 
yang bertugas mengadakan pemeriksaan perkara pidana dan juga mengadakan pengawasan dan pengamatan.

Pengadilan Negeri Sengeti adalah salah satu pengadilan tingkat pertama dalam lingkungan peradilan umum di Kabupaten Muaro Jambi.Pengadilan dengan tipe/kelas B yang daerah hukumnya meliputi daerah Kabupaten Muaro Jambi.

Undang-Undang Nomor 48 Tahun 2009 tentang Ketentuan-ketentuan Pokok Kekuasaan Kehakiman didalam Pasal 1 mengatur :

Kekuasaan Kehakiman adalah kekuasaan negara yang merdeka untuk menyelenggarakan peradilan guna menegakkan hukum dan keadilan berdasarkan Pancasiladan Undang-Undang Dasar Negara Republik Indonesia Tahun 1945, demi terselenggaranya Negara Hukum Republik Indonesia.

Artinya bahwa hakim didalam menegakkan hukum dan keadilan dengan menyidangkan dan memutuskan perkara tidakdapat dipengaruhi orang lain atau pihak manapun. Selanjutnya didalam Pasal 18 bahwa:

Kekuasaan kehakiman dilakukan oleh sebuah Mahkamah Agung dan badan peradilan yang berada di bawahnya dalam lingkungan peradilan umum, lingkungan peradilan agama, lingkungan peradilan militer, lingkungan peradilan tata usaha negara, dan oleh sebuah Mahkamah Konstitusi.

Kekuasaan Kehakiman dalam lingkungan peradilan umum dilaksanakan oleh :

1.Pengadilan Negeri

2.Pengadilan Tinggi

3.Mahkamah Agung

Adapun tugas pokok hakim pada peradilan umum tersebut diatas, adalah memeriksa, mengadili, serta menyelesaikan setiap perkara pidana maupun perkara perdata. Atas dasar tuntutan jaksa penuntut umum yang menyusun surat dakwaannya berdasarkan Berita Acara Pemeriksaan dari penyidik (BAP).

Pada tahap penuntutan, jaksa penuntut umum menyusun surat dakwaan berdasarkan Berita Acara Pemeriksaan dari penyidik, setelah penuntut umum melakukan penuntutan yaitu melimpahkan perkara ke Pengadilan Negeri dengan permintaan segera mengadili perkara tersebut pada suatu waktu yang ditentukan oleh hakim. Maka ketua pengadilan yang telah menerima pelimpahan perkara, mempelajari apakah perkara tersebut termasuk wewenang pengadilan yang diketuai olehnya berdasarkan tempatdimana tindak pidana dilakukan (locus delicti commisi). 
Majelis yang mengadili suatu perkara setelah melakukan seluruh tahapan acara persidangan akhirnya memutuskan perkara tersebut dengan mempergunakan alat-alat bukti sebagaimana diatur dalam Pasal 183 KUHAP yang berbunyi :

Hakim tidak boleh menjatuhkan pidana kepada seseorang kecuali dengan sekurang-kurangnya dua alat bukti yang sah dan ia memperoleh keyakinan bahwa suatu tindak pidana benar-benar terjadi dan bahwa terdakwalah yang bersalah karena telah melakukan suatu tindak pidana.

Pengadilan Negeri Sengeti adalah institusi atau lembaga tempat Hakim Pengawas dan Pengamat Pengadilan Negeri Sengeti melaksanakan tugas pokoknya sehari-hari. Tugas pokok Hakim Pengadilan Negeri Sengeti sebagaimana tugas pokok Hakim Pengadilan Negeri pada umumnya dalam perkara pidana yang telah disebutkan diatas tadi adalah menerima, memeriksa, mengadili, dan menyelesaikan perkara yang berdasarkan asas bebas, jujur, dan tidak memihak serta berintikan kepastian hukum dan keadilan di daerah Kabupaten Muaro Jambi. Pengawasan dan pengamatan memang bukan tugas pokok para Hakim, melainkan hanya merupakan tugas khusus. Di dalam Pasal 277 ayat (1) KUHAP dinyatakan :

Pada setiap pengadilan harus ada hakim yang diberi tugas khusus untuk membantu ketua dalam melakukan pengawasan dan pengamatan terhadap putusan pengadilan yang menjatuhkan pidana perampasan kemerdekaan.

Organisasi Pengadilan Negeri Sengeti dipimpin oleh oleh Ketua Pengadilan Negeri dibantu oleh Wakil Ketua Pengadilan, Panitera/Sekretaris, dan wakil Panitera.

Panitera adalah menangani administrasi perkara-perkara atau disebut masalah teknis yang terdiri dari:

1.Panitera muda perdata ;

2.Panitera muda pidana;

3.Panitera muda hukum.

Sekretaris adalah menangani administrasi pengadilan non teknis yang terdiri dari :

1.Kaur kepegawaian ;

2.Kaur keuangan ;

3.Kaur umum. 
Disamping panitera/sekretaris tersebutdiatas, terdapat majelis hakim yang mempunyai tugas pokok memeriksa, mengadili, dan memutuskan suatu perkara yang diserahkan kepadanya.Hakim di Pengadilan Negeri

Selain melaksanakan tugas pokok, beberapa diantara Hakim masih diberikan tugas tambahan oleh ketua pengadilan untuk membantu ketua pengadilan dalam bidang :

1.Pengawas bidang Pidana

2.Pengawas bidang Perdata

3.Pengawas bidang Hukum

4.Pengawas bidang Umum

5.Pengawas bidang Personalia/Kepegawaian

6.Pengawas bidang Notaris/Pengacara

7.Pembimbing Mahasiswa

8.Pengawas dan Pengamat pelaksanaan putusan pidana.

Pada umumnya, tugas pengawasan tersebut di atas adalah mengurusi masalah ketertiban, keteraturan, dan kesempurnaan administrasi atas jalannya pekerjaan di masingmasing bidang.Misalnya : pengawas bidang pidana adalah untuk mengawasi masalah ketertiban, keteraturan, dan kesempurnaan administrasinya apakah sudah dimasukkan di buku register atau pendaftaran, apakah sudah didistribusikan pada hakim,apakah sudah disidangkan, diputus, dan sebagainya.

Demikian juga bidang-bidang lainnya,akhirnya pada suatu ketika Ketua Pengadilan Negeri meminta laporan pekerjaan masing-masing pengawas.Dasar dari pelaksanaan tugas itu adalah diterbitkannya SK (Surat Keputusan) oleh Ketua Pengadilan Negeri.Khusus halnya dengan Hakim Pengawas dan Pengamat yang mengawasi dan mengamati pelaksanaan hukuman selama narapidana menjalani hukumannya di dalam Lembaga Pemasyarakatan, jadi bukan sekedar pengawasan administratif.Untuk wilayah Kabupaten Muaro Jambi sampai saat ini belum ada terdapat Lembaga Pemasyarakatan oleh karenanya sampai saat ini tahanan dan narapidana ditempatkan pada Lembaga Pemasyarakatan Klas IIA Jambi.

Apabila dihubungkan dengan penelitian ini, maka yang dimaksud dengan implementasi tugas Hakim Pengawas danPengamat dalam melakukan pengawasan dan pengamatan terhadap narapidana. Menurut Hakim Pengawas Pengadilan Negeri Sengeti:

Implementasi tugas Hakim Pengawas danPengamat dalam melakukan pengawasan dan pengamatan terhadap narapidanaadalah seperangkat kegiatan yang secara nyata telah 
dilakukan oleh hakim yang ditunjuk Ketua Pengadilan sebagai Hakim Pengawas dan Pengamat untuk melakukan pengamatan terhadap narapidana selama mereka menjalani masa pidanaya terutama mengenai perilaku mereka masing-masing maupun perlakuan para petugas Lembaga Pemasyarakatan terhadap diri narapidana itu sendiri. Dengan demikian hakim selain akan dapat mengetahui sampai dimana putusan pengadilan tampak hasil baik buruknya pada diri narapidana yang bersangkutan, juga penting bagi penelitian yang bermanfat bagi pemidanaan. ${ }^{8}$

Alur proses pelaksanaan tugas Hakim Pengawas dan Pengamat adalah sebagai berikut:

Setelah pengadilan menjatuhkan hukuman perampasan kemerdekaan kepada terpidana adalah menjadi tugas dan tanggung jawab Jaksa mengeksekusi atau melaksanakan keputusan tersebut. Artinya, Jaksalah yang membawa terpidana ke Lembaga Pemasyarakatan dan bersama-sama dengan petugas Lembaga Pemasyarakatan untuk memasukkan terpidana ke dalam suatu kamar sebagai tempat narapidana tersebut melaksanakan hukuman, kemudian dibuatlah barita acara pelaksanaan hukuman yang ditandatangani oleh Jaksa, Kepala Lembaga Pemasyarakatan, dan terpidana.

Setiap ada terpidana yang akan menjalani masa hukuman di dalam Lembaga Pemasyarakatan, oleh pihak Lembaga Pemasyarakatanmeminta surat turunan putusan Hakim, Berita Acara Pemeriksaan Eksekusi, Berita Acara Penahanan dari Kepolisian, Berkas Penahanan dari Jaksa, kepada pihak Pengadilan Negeri. Jika berkas-berkas tersebut tidak dilengkapi, maka terpidana tersebut masih dianggap berstatus sebagai tahanan, sehingga tidak bisa dilakukan eksekusi dan tidak dapat diusulkan remisi terhadap narapidana tersebut.

Setiap kali pihak Lembaga Pemasyarakatan meminta berkas-berkas kepada pihak pengadilan Negeri Sengeti, pihak Lembaga Pemasyarakatan jarang sekali menerima secara konkrit tembusan putusan tersebut walaupun pihak Lembaga Pemasyarakatan telah berkali-kali menyurati pihak pengadilan Negeri Sengeti. Hal ini baru mendapatkan tanggapan pihak pengadilan Negeri Sengeti setelah pihak Lembaga Pemasyarakatan melakukan pemberitahuan kepada Mahkamah Agung dalam jangkawaktu yang sangat lama.

${ }^{8}$ Ultry Meilizayeni, Hakim Pengawas dan Pengamat Pengadilan Negeri Sengeti, wawancara tanggal 26 September 2014 
Tanggung jawab para Hakim tidak hanya berhenti setelah menjatuhi pidana atau memvonis seseorang, melainkan tanggung jawab tersebut tetap harus mengalir sampai terpidana menjalani masa hukuman hingga terpidana tersebut bebas, yang diperantarai oleh salah satu Hakim yang ada, yakni Hakim Pengawas dan Pengamat.

Alasannya, karena kerap kali terjadi para Hakim tersebut lupa akan pidana atau vonis yang telah dijatuhkan olehnyaterhadap terpidana. Hal ini menunjukkan ketidakefektifan proses administrasi serta kinerja para Hakim di Pengadilan Negeri Sengeti tersebut.

Peranan Lembaga Pemasyarakatan sebagai salah satu tempat membina narapidana sangat potensial dan strategis menuntut adanya perhatian dan kepedulian dari semua pihak khususnyaHakim Pengawas dan Pengamat agar meningkatkan kualitas peranannya di Lembaga Pemasyarakatan untuk mengawasi dan mengamati pelaksanaan putusan pidana sehingga narapidana menjadi baik sewaktu kembali bebas ke masyarakat.

Kunjungan Hakim Pengawas dan Pengamat ke Lembaga Pemasyarakatan telah diatur oleh Undang-Undang paling sedikit 3 (tiga) bulan sekali.Kunjungan Hakim Pengawas dan Pengamat tersebut (checking on the spot)dilakukan untuk memeriksa agar mengetahui atas kebenaran berita acara pelaksananaan putusan pengadilan apakah terpidana telah diserahkan ke Lembaga Pemasyarakatan tepat pada waktunya, dan apakah masa pidanayang dijatuhkan telah dilaksanakan secara nyata oleh Lembaga Pemasyarakatan.

Mengenai kunjungan Hakim Pengawas dan Pengamat, menurut narapidana mengatakan bahwa di Lembaga Pemasyarakatantidak mengetahui dengan pasti frekuensi kedatangan Hakim Pengawas dan Pengamat di Lembaga Pemasyarakatan dan berapa kali seharusnya datang di Lembaga Pemasyarakatan. Hal mana disebabkan karena kedatangan Hakim Pengawas dan Pengamat sendiri yang masih kurang lancar sesuai dengan waktu yang telah diatur oleh Undang-Undang yaitu minimal 3 bulan sekali.

Ketidakjelasan mengenai kunjungan Hakim Pengawas dan Pengamat ini menyebabkan Hakim Pengawas dan Pengamat tidak pernah bersosialisasi dengan pihak Lembaga Pemasyarakatan, baik dengan para petugas,pegawai, maupun para narapidana di dalamnya. Sehingga tidak sedikit narapidana yang tidak mengetahui mengenai adanya suatu lembaga yang disebut Hakim Pengawas dan Pengamat.

Petunjuk pelaksanaan tugas Hakim Pengawas dan Pengamat diatur dalam Surat Edaran Mahkamah Agung (SEMA) Nomor 7 Tahun 1985. Berikut ini penulis jabarkan 
tugas Hakim Pengawas dan Pengamat tersebut dan dikaitkan dengan implementasinya dilapangan perspektif HakimPengawas dan Pengamat Pengadilan Negeri Sengeti :

1. Pengawasan ditujukan kepada Jaksa dan Petugas Lembaga Pemasyarakatan dalam hal :

a. Memeriksa dan menandatangani register pengawasan dan pengamatan seperti yang telah penulis uraikan dimuka, setelah pengadilan menjatuhkan hukuman kepada terpidana, adalah menjadi tanggung jawab Jaksa untuk mengeksekusi terpidana tersebut.Kemudian dibuat berita acara pemeriksaan pelaksanaan hukuman yang ditandatangani oleh Jaksa, Kepala Lembaga Pemasyarakatan, dan terpidana. Berdasarkan berita acara pelaksanaan hukuman tersebut dibuatlah surat register pengawasan dan pengamatan yang terdapat dikepaniteraan Pengadilan Negeri Sengeti untuk ditandatangani oleh Panitera dan Hakim Pengawas dan Pengamat.

Berdasarkan hasil penelitian penulis dilapangan ternyata pemeriksaan, pengisian, dan penandatanganan register pengawasan dan pengamatan tidak dilakukan oleh Hakim Pengawas dan Pengamat, melainkan hanya menandatangani suatu surat berupalaporan yang menyatakan bahwa terpidana telah dieksekusi berdasarkan Berita Acara Pemeriksaan eksekusi yang dibuat oleh bagian pidana. Tidak dilaksanakan penandatangan register tersebut adalah disebabkan kesibukan Hakim dan Panitera dalam menjalankan tugas pokoknya sehari-hari, yaitu memeriksa, mengadili dan menyelesaikan perkara-perkara yang didistribusikan kepadanya.

Padahal, menurut SEMA Nomor 7 Tahun 1985 huruf (a) ini bahwa salah satu tugas Hakim Pengawas dan Pengamat adalah memeriksa dan menandatangani register pengawasan dan pengamatan yang ada di KepaniteraanPengadilan Negeri Sengeti. Artinya, setiap ada tembusan berita acara pelaksanaan hukuman yang dikirimkan oleh Jaksa Penuntut Umum seharusnyadiperiksa dan ditandangani oleh Hakim Pengawas dan Pengamat.

Pengawasannya selama ia diangkat menjadi Hakim Pengawas dan Pengamat diantaranarapidana tersebut tidak atau belum pernah ada yang melarikan diri dan jumlah narapidana yang dikirim oleh Jaksa Penuntut Umum telah sesuai dengan data yang ada di Pengadilan Negeri Sengeti dan telah melaksanakan hukuman sebagaimana mestinya.Mengingat terbatasnya waktu dari Hakim Pengawas dan Pengamat itu sendiri 
alangkah baiknya bila jumlah Hakim Pengawas dan Pengamat di Pengadilan Negeri Sengeti yang hanya 1 (satu) orang, ditambah lagi sehingga dapat berbagi tugas.

\section{b.MengadakanChecking on the Spot}

Saat memberikan keterangan, Hakim Pengawas dan Pengamat menambahkan bahwa kunjungan Hakim Pengawas dan Pengamat ke Lembaga pemasyarakatan sangat perlu dilakukan.Alasannya bahwa Hakim sebagai perpanjangan tangan Tuhan yang telah menjatuhkan hukuman kepada terdakwa harus mengetahui perihal hukuman yang telah dijatuhkan olehnya tersebut.Apakah telah dilaksanakan sesuai dengan sebagaimana mestinya.

Yang menjadi kendala dalam melakukan kunjungan Hakim Pengawas dan Pengamat ke Lembaga Pemasyarakatan Klas IIA Jambi adalah kesibukan hakim melaksanakan kegiatannya sehari-hari di Pengadilan Negeri Sengeti.Seperti yang kita ketahui bahwa tugas pokok Hakim adalah memeriksa, mengadili, dan memutuskan suatu perkara yang diserahkan kepadanya. Sehingga jauh sebelum hakim Pengawas dan Pengamatakan melakukan kunjungan, Hakim Pengawas dan Pengamat harus mengagendakan rencana kunjungannya tersebut dengan menetapkan tidak ada perkara yang disidangkan pada hari tersebut.

c.Mengadakan Observasi

Hakim Pengawas dan Pengamat dalam mengadakan observasi atas keadaan, suasana dan kegiatan-kegiatan yang berlangsung dalam lingkungan tembok-tembok Lembaga Pemasyarakatan. Dengan mengadakan observasi Hakim Pengawas dan Pengamat dapat mengamati perilaku narapidana sehubungan dengan hukumannya, demikian juga dengan bimbingan kerja yang dilakukan apakah sudah membawa perbaikan bagi dirinya dan merupakan suatu pekerjaan yang dapat menjadi bekal atau modal dikemudian hari setelah bebas dari Lembaga Pemasyarakatan.

d. Melakukan Wawancara dengan Para Wali Pembina

Dalam SEMA Nomor 7 Tahun 1985 diatur bahwa Hakim Pengawas dan Pengamat mengadakan wawancara dengan para wali pembina tentang pembinaan narapidana apakah telah dilaksanakandengan baik sebagaimana mestinya dan bagaimana hasilnya. 
Menurut keterangan yang diberikan oleh Hakim Pengawas dan Pengamat, saat melakukan kunjungan ke Lembaga Pemasyarakatan tidak ada melakukan wawancara dengan para wali pembina, melainkan hanya sekedar mewawancarai narapidana saja. ${ }^{9}$

e.Wawancara dengan Narapidana

Selain melakukan wawancara denganpara wali pembina, SEMA Nomor 7 Tahun 1985 juga mengatur bahwa Hakim Pengawas dan Pengamat dalam kunjungannya ke Lembaga Pemasyarakatan mengadakan wawancara dengan narapidana untuk mengetahuibagaimana perlakuan petugas Lembaga Pemasyarakatan pada mereka dan apakah sering terjadi perkelahian antara narapidana, apa yang menjadi penyebab dan hukuman apa yang diberikan oleh petugas Lembaga Pemasyarakatan.

Setiap kali melakukan kunjungan hakim Pengawas dan Pengamat ada melakukan wawancara dengan narapidana baik mengenai pembinaandi dalam Lembaga Pemasyarakatan, perkelahian antara narapidana, bidang-bidang kerajinan tangan dan pelatihan kerja yang ditekuni oleh narapidana dan lain-lain. Wawancara ini dilakukan oleh Hakim Pengawas dan Pengamat dengan cara mewawancarai secara acak salah satu narapidana yang diklasifikasikan berdasarkan jenis tindak pidana yang dilakukan. Misalnya hakim Pengawas dan Pengamat mewawancarai salah satu narapidana dengan klasifikasi tindak pidana pembunuhan, kemudian hakim Pengawas dan Pengamat melakukan wawancara dengan narapidana dengan klasifikasi tindak pidana narkotika, begitu seterusnya.

2. Sedangkan pengamatan ditujukan pada masalah pengadilan sendiri sebagai penelitian bagi pemidanaan yang akan datang, yaitu :

a. Mengumpulkan data tentang perilaku narapidana, yang dikategorikan berdasarkan jenis tindak pidananya (misalnya pembunuhan, perkosaan, dan sebagainya). Data mengenai perilaku narapidana ini dapat berpedoman pada faktor-faktor antaralain : Tipe dari perilaku tindak pidana (misalnya untuk pertama kali melakukan tindak pidana (non residivis), pengulangan tindak pidana (residivis), dan sebagainya), keadaan rumah tangganya (baik-baik, bobrok, dan sebagainya), perhatian keluarganya terhadap dirinya (besar sekali, kurang perhatian, dan sebagainya), keadaan lingkungannya (tunasusila, dan sebagainya), catatan pekerjaannya (pengangguran, dan sebagainya), catatan

${ }^{9}$ Ultry Meilizayeni, Hakim Pengawas dan Pengamat Pengadilan Negeri Sengeti, wawancara tanggal 26 September 2014 
kepribadiannya (tenang, egosentris, dan sebagainya), jumlah teman-teman dekatnya (satu, dua, tiga, atau lebih, keadaan psykhisnya dan lain-lain.

b. Mengadakan evaluasi mengenai hubungan antara perilaku narapidana tersebut dengan pidana yang dijatuhkan, apakah lamanya pidananya yang dijatuhkan terhadap narapidana dengan perilaku tertentu sudah tepat (dalam arti cukup) untuk melakukan pembinaan terhadap dirinya sehingga pada waktu dilepaskan nanti, narapidana tersebut sudah dapat menjadi anggota masyarakat yang baik dan taat kepada hukum.

Walaupun Hakim Pengawas dan Pengamat telah berjalan puluhan tahun sebagai pengamat untuk kepentingan (sentencing policy) akan tetapi berdasarkan hasil penelitian di lapangan bahwa sebagian besar narapidana merasa hukumannya tidak sesuai dengan perbuatan yang telah dilakukan. Bahkan ada narapidana yang mengaku tidak pernah melakukan perbuatan apapun tetapi dihukum dengan hukuman yang berat.

Berikut uraian mengenai sistem hukum dikaitkan dengan permasalahan yang diajukan.

Pertama, adalah struktur (structure)yang pada permasalahan ini dititikberatkan pada hakim sesuai dengan ketentuan yang terdapatdalam Pasal 277 sampai dengan Pasal 283 KUHAP. Namun disisi lain terkait pula lembaga penerap sanksi yang berperan dalam tugas Hakim Pengawas dan Pengamat yaitu aparat Lembaga Pemasyarakatan.

Ketentuan Pasal 278 KUHAP di Pengadilan Negeri Sengeti, bahwa pencatatan berita acara pelaksanaan putusan pengadilan selalu dicatat dalam register pengawasan dan pengamatan.

Ketentuan Pasal 279 KUHAP di Pengadilan Negeri Sengeti dilaksanakan secara teratur berdasarkan ketentuan undang-undang. Ketentuan Pasal 280 ayat (1) KUHAP ini kurang berjalan dengan efektif, menurut Wakil Panitera Pengadilan Sengeti bahwa:

Kendala yang dihadapi antara lain kesibukan hakim di Pengadilan Negeri Sengeti, sehingga tidak memungkinkan untuk melakukan tugas mengawasi dan mengamati. Selain kesibukan hakim, tidak didukung oleh sarana dan prasarana yang memadai, antara lain anggaran operasional yang tidak ada. ${ }^{10}$

Tugas dari Hakim Pengawas dan Pengamat tidak hanya melakukanpengawasan saja namun juga malakukan pengamatan terhadap terpidana, Berdasarkan hasil wawancara dengan Hakim Pengawas danPengamat di Pengadilan Negeri Sengeti sama halnya dengan

\footnotetext{
${ }^{10}$ Julianto, Wakil Panitera Pengadilan Negeri Sengeti, wawancara tanggal 26 September 2014
} 
pengawasan, pengamatanpun di Pengadilan Negeri Sengeti kurang berjalan dengan efektif, kendala yang dijelaskan oleh narasumberpun sama dengan kendala yang dihadapi dalam pelaksanaan tugas pengawasan. ${ }^{11}$

Ketentuan Pasal 280 ayat (4) KUHAP di Pengadilan Negeri Sengeti kurang berjalan sesuai ketentuan undang-undang.Hal ini disebabkan karena tidak didukungnya sarana dan prasarana yang memadai.

Penerapan Pasal 281 KUHAP di Pengadilan Negeri Sengeti Hakim Pengawas dan Pengamat sebelum melakukan checking on the spot ke Lembaga Pemasyarakatan terlebih dahulu meminta data dan menanyakan kondisi serta situasi yang ada di Lembaga Pemasyarakatan Klas IIA Jambi, dan juga membawa suatu kartu yang dinamakan Kartu Data Perilaku Narapidana, kartu tersebut berisikan antara lain : nama, jenis tindak pidana yang dilakukan, lama pidana yang dijatuhkan, tipe pelaku tindak pidana, keadaan rumah tangga, perhatian keluarga, dan lain-lain. Kemudian penerapan Pasal 282 KUHAP di Pengadilan Negeri Sengeti tidak berjalan dengan maksimal, hal ini dikarenakan Hakim Pengawas dan Pengamat tidak pernah diajak bersama untuk merumuskan cara atau teknis pembinaan di Lembaga Pemasyarakatan Klas IIA Jambi

Penerapan Pasal 283 KUHAP di PengadilanNegeri Sengeti berjalan efektif dan tidak ditemukan hambatan karena dari hasil kerja dilakukan secara sekaligus. Berdasarkan uraian sebagaimana tersebut diatas, maka dapat dikatakan bahwa tugas yang dijalankan Hakim Pengawas dan Pengamat tersebut pada hakekatnya sebagai akibat dari respon terhadap peraturan-peraturan yang mengaturnya baik yang terdapat dalam Kitab Undangundang Hukum Acara Pidana (KUHAP) maupun Surat Edaran Mahkamah Agung Nomor 7 Tahun 1985.Namun demikian, berdasar hasil penelitian pula, tampaknya Hakim Pengawas dan Pengamat dalam tugasnya tidak terlepas dari keseluruhan kompleks kekuatan-kekuatan sosial, politik, ekonomi, teknologi, dan lain-lainnya.

Berdasarkan penelitian pelaksanaan ketentuan Pasal 280 ayat (3) KUHAP sendiri di Pengadilan Negeri Sengeti kurang berjalan efektif, kendala yang disampaikan pun kurang lebih sama dengan pengawasan dan pengamatan. Hal yang membedakan, kendala dalam pelaksanaan Pasal 280ayat (3) KUHAP adalah setelah narapidana selesai menjalani pidananya atau keluar dari Lembaga Pemasyarakatan, Kepala Lembaga Pemasyarakatan

${ }^{11}$ Ultry Meilizayeni, Hakim Pengawas dan Pengamat Pengadilan Negeri Sengeti, wawancara tanggal 26 September 2014 
tidak memberitahukan atau tidak mengirim surat ke pengadilan negeri, sehingga Hakim Pengawas dan Pengamat tidak mengetahui bahwa narapidana tersebut telah bebas.

Selain itu juga letak rumah atau tempat tinggal terpidana tersebut sulit dijangkau, misalkan perkara disidangkan di Pengadilan Negeri Sengeti, namun terpidana tersebut berasal dari luar provinsi sehingga menimbulkan kesulitan dalam melakukan pengamatan dan dalam ketentuan Pasal 280 ayat (4) KUHAP di Pengadilan Negeri Sengeti kurang berjalan sesuai ketentuan undang-undang. Hal ini disebabkan karena tidak didukungnya sarana dan prasarana yang memadai.

Berdasarkan ketentuan-ketentuan diatas,maka keseluruhan kompleks kekuatan sosial disini dimaksudkan adanya pengaruh yang meliputi kurangnya tenaga administrasi yang membantu tugas Hakim Pengawas dan Pengamat, sulitnya memantau para narapidana yang dijatuhi hukuman pidana bersyarat serta sulitnya memantau para bekas narapidana yang telah selesai menjalankan pidananya.

Disamping itu tampaknya terdapat pula kendala yang cukup serius bagi tugas Hakim Pengawas dan Pengamatberupawaktu yang tersedia untuk menjalankan tugas tersebut, hal ini tidak dapat dipungkiri mengingat bahwa Hakim sudah mempunyai tugas yang cukup menyita waktu berupa memimpin sidang di pengadilan. Kondisi seperti ini tampaknya akan lebih memprihatinkan apabila tempat dimana Hakim Pengawas dan Pengamat bertugas merupakan daerah yang cukup tinggi jadwal persidangannya.

Demikian pula halnya dengan Lembaga Pemasyarakatan yang dalam menjalankan tugas pembinaan dan pembimbingan warga binaan pemasyarakatan sebagian besar berdasarkan pada Peraturan Pemerintah Republik Indonesia Nomor 32 Tahun 1999 tentang Pembinaan dan Pembimbingan Warga Binaan Pemasyarakatan. Petugas Lembaga Pemasyarakatan dalam menjalankan tugasnya juga tidak terlepas dari keseluruhan kompleks kekuatan-kekuatan sosial, politik, dan lain-lainnya.

Berdasarkan hasil penelitian tugas yang dilaksanakan sudah cukup baik dalam artian sudah sesuai dengan norma-norma yang mengaturnya.Keseluruhan kompleks kekuatan-kekuatan sosial yang berpengaruh terlihat adanya kurang keterpaduan atau kurang koordinasi antara petugas Lembaga Pemasyarakatan dengan tugas Hakim Pengawas dan Pengamat. Hal ini dapat terjadi mengingat Hakim yang bertugas seringkali mengalami perubahan sebagai akibat pemindahan tempat tugas ke daerah lain.

Lebih lanjut Kepala Seksi Bimbingan Narapidana dan Anak Didik mengatakan bahwa disisi lain fasilitas yang tersedia dalam lingkungan Lembaga Pemasyarakatan serta 
kuantitas dan kualitas petugas cenderung kurang mendukungadanya pembinaan narapidana sebagai realisasi atas tujuan pemidanaan itu sendiri.

Berkaitan dengan substansi hukum. Di Indonesia,pembuatan peraturan undangundang berdasarkan ketentuan yang terdapat dalam amandemen keempat Undang-Undang Dasar 1945 Pasal 20 ayat (1) dilakukanoleh Dewan Perwakilan Rakyat (DPR) dengan persetujuan bersama Presiden.

Ketentuan yang dibuat berupa Kitab Undang-undang Hukum Acara Pidana (KUHAP) yang menjadi landasan pokok dari tugas Hakim Pengawas dan Pengamat ini merupakan hasil umpan balik dari struktur maupun kultur hukum yang memandang bahwa ketentuan yang lama berupa Reglemen Indonesiayang diperbaharui atau di kenal dengan nama "Het Herzine Inlandsch Reglement" Stb. 1941 Nomor 44 sudah tidak sesuai lagi dengan falsafah bangsa Indonesia yang berdasarkan Pancasila dan Undang-Undang Dasar 1945.

Dengan mengingat peraturan yang terdapat dalam Pasal 277 sampai dengan Pasal 283 Kitab Undang-Undang Hukum Acara Pidana (KUHAP) belum mengatur secara operasional tentang tugas Hakim Pengawas dan Pengamat maka Mahkamah Agung berdasarkan Pasal 79 Undang-Undang Nomor 5 Tahun 2004tentang Perubahan atas Undang-Undang Nomor 14 Tahun 1985 tentang Mahkamah Agung dimana menentukan bahwa Mahkamah Agung dapat mengatur lebih lanjut hal-hal yang diperlukan lagi bagi kelancaran penyelenggaraan peradilan apabila terdapat hal-hal yang belumcukup dalam peraturan Kitab Undang-undang Hukum Acara Pidana, maka untuk memfungsionalisasikan Kitab Undang-Undang Hukum Acara Pidana, Mahkamah Agung membuat peraturan sebagai pelengkap yang tertuang dalam Surat Edaran Mahkamah Agung Nomor 7 Tahun 1985 tentang Petunjuk Pelaksanaan Tugas Hakim Pengawas dan Pengamat.

Selain peraturan tersebut diatas, sebagai pendukung terhadap tujuan pemidanaan juga diterbitkan Peraturan Pemerintah Republik Indonesia Nomor 32 Tahun 1999 tentang Pembinaandan PembimbinganWarga Binaan Pemasyarakatan, yang memuat antara lain pengertian, program pembinaan dan pembimbingan, pelaksanaan pembinaan dan pembimbingan, faktoryangmempengaruhi pembinaan, sarana pembinaan serta pelaksanaan pengawasan. Dalam peraturan perundang-undangan tersebut disebutkan bahwa dalam hal pelaksanaan pidana penjara diterapkan suatu konsep yang disebut sistem pemasyarakatan 
yang dalam pertumbuhannya tidak terlepas dari perkembangan teori-teori pemidanaan serta kondisi masyarakat.

Dalam ketentuan Pasal 55 ayat (2) Undang-Undang Nomor 48 Tahun 2009 tentang Kekuasaan Kehakimanmenyatakan bahwa pengawasan pelaksanaan putusan pengadilan sebagaimana dimaksud pada ayat (1) dilakukan sesuai dengan peraturan perundangundangan.

Pengawasan pelaksanaan putusan pengadilan yang dilakukan oleh Ketua Pengadilan yang dalam hal ini diwakilkan oleh Hakim Pengawas dan Pengamat dilakukan sesuai dengan peraturan perundang-undangan, sementara dalam hal ini belum ada peraturan perundang-undangan yang secara khusus mengatur tentang pelaksanaan tugas Hakim Pengawas dan Pengamat, karena Sumber hukum pelaksanaan tugas Hakim Pengawas dan Pengamat belum memenuhi standar peraturan perundang-undangan, dalam melaksanakan tugasnya hanya berpedoman kepada Surat Edaran Mahkamah Agung yang hanya berlaku untuk internal lembaga Mahkamah Agung dan peradilan dibawahnya. Sehingga tidak mengikat pihak lain atau hanya berlaku secara internal Mahkamah Agung saja.

Berkaitan dengan kultur hukum. Kultur hukum merupakan sikap manusia terhadap hukum dan sistem hukum, didalamnya terdapat kepercayaan nilai, pemikiran, serta harapannya. Kultur hukum juga dapat dikatakan sebagai apa atau siapa saja yang memutuskan untuk menghidupkan dan mematikan stuktur hukum itu. Dalam kaitan dengan permasalahanyang ada maka yang menjadi kultur hukum adalah terpidana dengan jenis pidana perampasan kemerdekaan, baik mereka yang pembebasan bersyarat, pidana penjara, maupun narapidana yang telah selesai menjalani pidananya.

Berdasarkan hasil penelitiandapat diketahui bahwa respon (narapidana) cukup positif atas tugas Hakim Pengawas dan Pengamat dalam rangka melakukanpengawasan dan pengamatanterhadap narapidana sebagai realisasi atas putusan yang telah dijatuhkan oleh hakim. Disamping itu para kultur hukum juga mendukung adanya tugas tersebut dalam kaitannya dengan pembinaan narapidana dengan sistem pemasyarakatan, mengingat dalam sistem pemasyarakatan dinyatakan bahwa menjatuhi pidana bukan merupakan tindakan balas dendam, terhadap narapidana tidak boleh ada penyiksaan baik berupa ucapan maupun tindakan, cara perawatan maupun penempatan. Ketentuan ini pada hakekatnya untuk menghormati dan menjunjung hak asasi manusia. 
Disisi lain disebutkan bahwa tugas Hakim Pengawas dan Pengamat diantaranya adalah sebagai pengawasan terhadap kepastian tentang pelaksanaan putusan pengadilan. Maksudnya apakah Lembaga Pemasyarakatan benar-benar melaksanakan putusan hakim seperti yang dikehendaki dalam vonisnya.

Tugas dan wewenang itu dimaksudkan untuk mengetahui seberapa jauh Lembaga Pemasyarakatan telah benar-benar melakukan pembinaan kepada narapidana secara manusiawi sesuai prinsip-prinsip pemasyarakatan yaitu narapidana memperoleh hakhaknya antara lain hak remisi, cuti, pembebasan bersyarat, integrasi, dan asimilasi.

2.hambatan dalam pelaksanaan tugas Hakim Pengawas dan Pengamat dan solusinya.

Hambatan yang dihadapi oleh seorang Hakim pengawas dan pengamat dalam menjalankan tugas dan wewenangnya, yaitu hambatan internal dan hambatan eksternal. ${ }^{12}$

1. Hambatan Internal

Hakim pengawas dan pengamat lebih memusatkan perhatiannya kepada perkara yang diperiksa pada persidangan, mengingat tugas pengawasan dan pengamatan bukan merupakan tugas pokok seorang hakim, namun hanya tugas tambahan yang diberi oleh ketua pengadilan negeri, maka waktu untuk melakukan pengawasan dan pengamatan di Lembaga Pemasyarakatan menjadi berkurang atau bahkan tidak ada waktu sama sekali.

2. Hambatan Eksternal

Terdiri dari:

a. Dana Penunjang

Pengawasan dan Pengamatan terbatas Selama ini belum ada ketentuan yang mengatur tentang dana yang tersedia untuk digunakan Hakim pengawas dan pengamat dalam melaksanakan tugasnya, sehingga Hakim tersebut melakukan pengawasan dan pengamatan atas saku Hakim itu sendiri, termasuk juga pembuatan laporan. Masalah hambatan ini sedikit banyak bisamempengaruhi pola kerja dalam pelaksanaan tugasnya.

a. Kurangnya Peraturan maupun Ketentuan tentang Tugas Hakim Pengawas dan Pengamat.

${ }^{12}$ Ultry Meilizayeni, Hakim Pengawas dan Pengamat Pengadilan Negeri Sengeti, wawancara tanggal 26 September 2014 
Ruang lingkup Hakim pengawas dan pengamat dalam tugasnya adalah mengawasi narapidana yang ada di Lembaga Pemasyarakatan di wilayah hukum Pengadilan Negeri tempat ia bertugas sehari-harinya. Ruang lingkup tugas hakim ini diperluas dengan adanya ketentuan Pasal 280 ayat (3) dan (4) KUHAP yang berisi pengawasan dan pengamatan juga ditujukan terhadap narapidana yang telah selesai menjalani pidananya dan terpidana bersyarat, namun tugas ini tidak diikuti dengan sejumlah ketentuan yang mengaturnya, sehingga Hakim pengawasan dan pengamat dalam melaksanakan tugasnya apabila masuk kedalam instasi lain di luar Lembaga Pemasyarakatan dapat dianggap mencampuri secara formal wewenang instansi lain.

b. Hambatan birokrasi penegak hukum lainnya.

Hambatan ini menyangkut kondisi birokrasi pemerintahan khususnya dibidang penegakan hukum. Untuk menjalankan tugas sebagai Hakim Pengawas dan Pengamat maka ada pihak lain atau intansi pemerintah juga harus terlibat demi pelaksanaan tugas tersebut. Terkadang masing-masing instansi memiliki ego masing-masing yang susah untuk disatukan.

Upaya untuk menanggulangi kendala yang dihadapi oleh hakim pengawas dan pengamat menurut Hakim Pengawas dan Pengamat yaitu:

1. Upaya Internal

a. Menaikkan anggaran untuk pelaksanaan tugas hakim Pengawas dan Pengamat.

Kurang efektifnya Pelaksanaan Tugas Hakim Pengawas dan Pengamat salah satu faktor yang paling berpengaruh adalah minimnya anggaran yang disediakan untuk pelaksanaan tugas dari hakim pengawas dan pengamat karena banyaknya anggaran yang diprioritaskan bukan untuk kepentingan pelaksanaan fungsi Hakim pengawas dan pengamat melainkan untuk kebutuhan lainnya.

a. Mengadakan koordinasi antar Instansi Negera yang terkait dengan pembinaan narapidana.

Mengatasi hambatan birokrasi penegak hukum lainnya bagi hakim Pengawas dan Pengamat yaitu dengan cara mengadakan koordinasi antar Instansi Negara yang terkait dengan persoalan pembinaan narapidana. Hal ini penting agar pembinaan terhadap narapidana dapat dilakukan dengan baik. 


\section{Upaya Eksternal}

Upaya ini ditujukan kepada Badan Legislasi atau Badan Pembuat Undang-Undang yaitu Dewan Perwakilan Rakyat (DPR).Hal ini dimaksudkan agar hakim pengawas dan pengamat dibuatkan payung hukum ataupun undang-undang yang lebih jelas yaitu yang berupa undang-undang yang mengatur lebih spesifik lagi dan lebih memberikan wewenang lebih untuk saling mengawasi antar instansi negara perihal pembinaan narapidana.

3. Pengaturan Sebaiknya Dimasa Yang Akan Datangtentang Peranan Hakim Pengawas Dan Pengamat

Konsepsi pembaharuan hukum pidana terkait peranan Hakim Pengawas dan Pengamat terhadap narapidana, dapat direkonstruksi dari kesimpulan sebelumnya bahwa ketidak-berhasilan pencapaian hakekat penegakan hukum melalui penjatuhan pidana antara lain disebabkan oleh adanya kelemahan dalam perumusan ketentuan KUHAP tentang peranan Hakim Pengawas dan Pengamat.

Oleh karena itu, agar tujuan penegakan hukum melalui penjatuhan pidana dapat dicapai, maka ketentuan Pasal 277 dan Pasal 280 KUHAP harus direvisi, sedemikian sehingga 4 (empat) kelemahan perumusan dalam kedua pasal tersebut dapat diatasi. Selaras dengan hal itu, maka konsepsi yang diajukan juga mencakup 4 (empat) asepek.Pertama berkaitan dengan adanya pertentangan norma antara ketentuan Pasal 277 dan Pasal 280 KUHAP, maka perumusan Pasal 277 ayat (1) KUHAP harus dirubah sedemikian rupa sehingga peranan Hakim Pengawas dan Pengamat mencakup terpidana yang menjalani pidana di Lembaga Pemasyarakatan, dan terpidana yang menjalani pidana di luar Lembaga Pemasyarakatan.

Oleh karena itu, perumusan Pasal 277 ayat (1) KUHAP dirubah dari semula:

Pada setiap pengadilan harus ada hakim yang diberi tugas khusus untuk membantu ketua dalam melakukan pengawasan dan pengamatan terhadap putusan pengadilan yang menjatuhkan pidana perampasan kemerdekaan.

Menjadi:

Pada setiap pengadilan harus ada hakim yang diberi tugas khusus untuk membantu ketua dalam melakukan pengawasan dan pengamatan terhadap putusan pengadilan yang menjatuhkan pidana baik berupa pidana perampasan kemerdekaan, maupun pidana bersyarat. 
Selanjutnya, menyangkut kelemahan kedua yakni bahwa pengaturan tentang peranan Hakim Pengawas dan Pengamat terhadap terpidana bersyarat tidak diatur di dalam pasal tersendiri, melainkan "hanya" sebagai tambahan atau pelengkap dari Pasal 280 KUHAP, maka di dalam KUHAP mendatang pengaturan mengenai kedudukan, tugas dan fungsi Hakim Pengawas dan Pengamat terhadap terpidana bersyarat harus diatur dalam pasal tersendiri, yang menggariskan secara jelas dan tegas tentang tugas dan fungsi Hakim Pengawas dan Pengamat khusus untuk terpidana bersyarat.

Perihal kelemahan yang ketiga, yakni adanya norma yang tidak jelas dan tegas tentang pengawasan terhadap terpidana bersyarat, konsepsi norma yang diajukan adalah menyebutkan dengan jelas dan tegas tentang cara Hakim Pengawas dan Pengamat melakukan tugas dan fungsinya mengawasi narapidana, dan pihak-pihak lain yang dilimpahkan wewenang untuk mengawasi dan mengamati secara langsung narapidana.

Karena yang bersentuhan langsung dengan narapidana adalah masyarakat, maka fungsi pengawasan dan pengamatan perubahan perilaku narapidana, pertama sekali harus dilakukan oleh aparat pemerintah terendah yakni Kepala Desa atau Kepala Kelurahan, melalui Ketua Rukun Tetangga (RT) dimana narapidana berdomisili. Hasil pengamatan langsung tersebut, kemudian secara berkala diteliti, diverifikasi dan dibuatkan rekomendasi oleh Balai Pemasyarakatan (BAPAS) Kementerian Hukum dan HAM. Hasil rekomendasi tersebutlah yang dijadikan oleh Hakim Pengawas dan Pengamat untuk menetapkan pengurangan atau penghentian masa percobaan atau mengahiri masa percobaan bagi terpidana yang berkelakuan baik, atau menetapkan pelaksanaan pidana perampasan kemerdekaan, bagi narapidana yang nyata-nyata melanggar persyaratan pemidanaan.

Kemudian daripada itu, terkait dengan kelemahan yang terakhir, yakni tidak adanya pengaturan di dalam KUHAP yang mengatur mengenai akibat hukum, apabila kewajiban Pengadilan untuk membentuk Hakim Pengawas dan Pengamat dan kewajiban untuk melakukan pengawasan dan pengamatan, tidak dilaksanakan sebagaimana mestinya. maka harus dirumuskan secara tegas bahwa pengadilan yang tidak memiliki Hakim Pengawas dan Pengamat, dan/atau memiliki Hakim Pengawas dan Pengamat namun tidak melaksanakan fungsinya sesuai amanat KUHAP, dikenakan sanksi adminitratif, dimana sanksi tersebut diatur lebih lanjut dalam Peraturan Pemerintah.

Berdasarkan konsepsi yang diajukan di atas, disimpulkan bahwa konsepsi pembaharuan hukum pidana tentang peranan Hakim Pengawas dan Pengamat yang sebaiknya diterapkan adalah norma hukum acara pidana yang mengatur secara jelas dan 
tegas tentang peranan Hakim Pengawas dan Pengamat terhadap perubahan perilaku narapidana, sedemikian sehingga setiap terjadinya penjatuhan pidana, dapat dipastikan bahwa narapidana tidak akan melakukan pengulangan tindak pidana, melalui mekanisme pengawasan yang ketat dan pengamatan yang cermat oleh Hakim Pengawas dan Pengamat, yang sebagian fungsinya dilimpahkan kepada Ketua RT/Desa/Kelurahan domisili narapidana dan Balai Pemasyarakatan, yang oleh undang-undang diberi kewenangan untuk melakukan penelitian kemasyarakatan terhadap narapidana.

\section{E. Kesimpulan}

Berdasarkan uraian pada bab terdahulu, maka dapat diambil beberapa kesimpulan sebagai berikut:

1. Implementasi tugas Hakim Pengawas danPengamat dalam melakukan pengawasan dan pengamatan terhadap narapidana adalah seperangkat kegiatan yang secara nyata telah dilakukan oleh hakim yang ditunjuk Ketua Pengadilan sebagai Hakim Pengawas dan Pengamat untuk melakukan pengamatan terhadap narapidana selama mereka menjalani masa pidanaya terutama mengenai perilaku mereka masingmasing maupun perlakuan para petugas Lembaga Pemasyarakatan terhadap diri narapidana itu sendiri. Dengan demikian hakim selain akan dapat mengetahui sampai dimana putusan pengadilan tampak hasil baik buruknya pada diri narapidana yang bersangkutan, juga penting bagi penelitian yang bermanfat bagi pemidanaan.

2. Hambatan yang dihadapi oleh seorang Hakim pengawas dan pengamat dalam menjalankan tugas dan wewenangnya, menurut Hakim Pengawas dan Pengamat Pengadilan Sengeti mengatakan terdapat 2 (dua) hambatan dalam pelaksanaan tugas dan fungsi Hakim Pengawas dan Pengamat yaitu hambatan internal dan hambatan eksternal.

3. Pengaturan sebaiknya dimasa depan tentang peranan Hakim Pengawas dan Pengamat yang sebaiknva diterapkan adalah norma hukum acara pidana yang mengatur secara jelas dar 129 tentang peranan Hakim Pengawas dan Pengamat terhadap perubahan perilaku narapidana, sedemikian sehingga setiap terjadinya penjatuhan pidana, dapat dipastikan bahwa terpidana tidak akan melakukan resedivisme, melalui mekanisme pengawasan dan pengamatan oleh Hakim 
Pengawas dan Pengamat, yang sebagian fungsinya dilimpahkan kepada Ketua RT/Desa/Kelurahan domisili narapidana dan Balai Pemasyarakatan.

\section{F. Rekomendasi}

1. Agar KUHAP mampu menjadi sarana hukum yang efektif untuk mencegah terjadinya pengulangan tindak pidana oleh narapidana, maka ketentuan Pasal 277 dan Pasal 280 KUHAP harus direvisi, sedemikian sehingga 4 (empat) kelemahan perumusan dalam kedua pasal tersebut dapat diatasi. Melarasi hal itu, maka konsepsi yang diajukan juga mencakup 4 (empat) aspek. Pertama perumusan Pasal 277 ayat (1) KUHAP harus dirubah sedemikian rupa sehingga peranan Hakim Pengawas dan Pengamat mencakup terpidana yang menjalani pidana di Lembaga Pemasyarakatan, dan terpidana. Kedua, di dalam KUHAP mendatang pengaturan mengenai kedudukan, tugas dan fungsi Hakim Pengawas dan Pengamat terhadap narapidana harus diatur dalam pasal tersendiri, yang menggariskan secara jelas dan tegas tentang tugas dan fungsi Hakim Pengawas dan Pengamat khusus untuk narapidana. Ketiga, mengatur cara Hakim Pengawas dan Pengamat melakukan tugas dan fungsinya mengawasi narapidana, dan pihak-pihak lain yang dilimpahkan wewenang untuk mengawasi dan mengamati narapidana secara langsung. Keempat, merumuskan secara tegas bahwa pengadilan yang tidak memiliki Hakim Pengawas dan Pengamat, dan/atau memiliki Hakim Pengawas dan Pengamat namun tidak melaksanakan fungsinya sesuai amanat KUHAP, dikenakan sanksi adminitratif, dimana sanksi tersebut diatur lebih lanjut dalam Peraturan Pemerintah.

2. Agar konsepsi mengenai peranan Hakim Pengawas dan Pengamat terkait pidana, dapat diwujudkan menjadi norma yang nyata, demi terjaminnya pencapaian hakekat pemidanaan, terutama pemidanaan bersyarat, maka revisi ketentuan KUHAP haruslah segera dilakukan.

\section{G. Daftar Pustaka}

Eddy Djunaedi Karnasudirdja,Beberapa Pedoman pemidanaan dan Pengamatan Narapidana, Bina Aksara, Jakarta,1996

Sudarto, Kapita Selekta Hukum Pidana, Alumni, Bandung, 1986

Oemar Seno Adji, Hukum Hakim Pidana, Erlangga, Jakarta,1989

Suryono Sutarto, Sari Hukum Acara Pidana, Yayasan Cendikia Purna Dharma, Semarang, 1990

Romli Atmasasmita, Sistem Peradilan, Perspektif Eksistensi, PT. PradnyaParamita, Jakarta, 1996 
Al Wisnubroto dan G Widiartana, Pembaharuan Hukum Acara Pidana, Citra Aditya, Bandung, 2005 